\title{
Conservation status of the only Lungless Frog Barbourula kalimantanensis Iskandar, 1978 (Amphibia: Anura: Bombinatoridae)
}

\author{
Biofagri A. Rachmayuningtyas ${ }^{1}$, David P. Bickford ${ }^{2}$, Mistar Kamsi ${ }^{3}$, Sujatha N. Kutty ${ }^{4}$, Rudolf Meier ${ }^{5}$, \\ Umilaela Arifin ${ }^{6}$, Angga Rachmansah ${ }^{7}$ \& Djoko T. Iskandar ${ }^{8}$ \\ 1,6,7,8 School of Life Sciences and Technology Institut Teknologi Bandung 10 Jalan Ganesa, Bandung 40132, Indonesia. \\ 2,4,5 Raffles Museum for Biodiversity Research, Department of Biological Sciences, National University of Singapore. 14 Science \\ Drive 4, Singapore 117543 \\ ${ }^{3}$ Sumatran Orangutan Conservation Program, 51/74 Jl. KH Wahid Hasyim Medan, 20154, Indonesia \\ ${ }^{7}$ Present address: Fauna \& Flora International, Indonesia Program, Ketapang, Kalimantan Barat, Indonesia. \\ Email: ${ }^{1}$ biofagri@yahoo.com, ${ }^{2}$ dbsbdp@nus.edu.sg, ${ }^{3}$ mistar234@gmail.com, ${ }^{4}$ sujatha@nus.edu.sg, ${ }^{5}$ dbsmr@nus.edu.sg, \\ ${ }^{6}$ umilaela@gmail.com, ${ }^{7}$ angga.rachmansah@gmail.com, ${ }^{8}$ iskandar@sith.itb.ac.id (corresponding author)
}

Date of publication (online): 26 August 2011 Date of publication (print): 26 August 2011 ISSN 0974-7907 (online) | 0974-7893 (print)

\section{Editor: Mirco Solé}

\section{Manuscript details:}

Ms \# 02560

Received 07 September 2010

Final received 26 July 2011

Finally accepted 04 August 2011

Citation: Rachmayuningtyas, B.A., D.P Bickford, M. Kamsi, S.N. Kutty, R. Meier, U Arifin, A. Rachmansah \& D.T. Iskandar (2011) Conservation status of the only Lungless Frog Barbourula kalimantanensis Iskandar, 1978 (Amphibia: Anura: Bombinatoridae). Journal of Threatened Taxa 3(8): xxxx-xxxx.

Copyright: (C) Biofagri A. Rachmayuningtyas, David P. Bickford, Mistar Kamsi, Sujatha N. Kutty, Rudolf Meier, Umilaela Arifin, Angga Rachmansah \& Djoko T. Iskandar 2011 Creative Commons Attribution 3.0 Unported License. JoTT allows unrestricted use of this article in any medium for non-profit purposes, reproduction and distribution by providing adequate credit to the authors and the source of publication.

For Author Detail, Author Contribution and Acknowledgements: see end of this article.
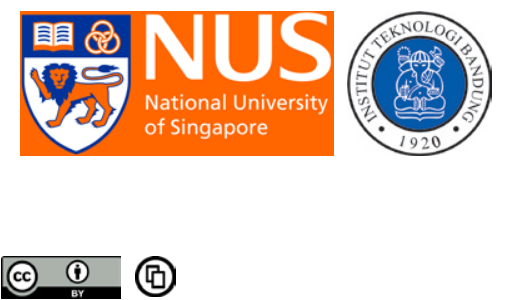

OPEN ACGESS | FREE DOWNLOAD
Abstract: In response to the recent rediscovery of Barbourula kalimantanensis, which is currently the only known lungless frog, a number of biologically important aspects of the species were examined and its taxonomy and conservation status was reviewed. Based on the species' ecological requirements, habitat restrictions and recent severe habitat loss, we propose to change the conservation status of Endangered B2ab(iii) to Vulnerable B1ab(iii) and earmark the species as a conservation flagship for the region and for Indonesia.

Keywords: Archeobatrachia, Borneo, distribution, flatheaded frog, Indonesia, national park, protection status.

Indonesian Abstract: Untuk melengkapi penemuan kembali setelah tiga puluh tahun dari Barbourula kalimantanensis, yang pada saat ini dikenal sebagai satu-satunya katak yang tak berparu-paru di dunia, telah dilakukan analisis dari sejumlah aspek biologi yang dianggap penting dalam meninjau ulang status perlindungannya. Atas dasar kebutuhan ekologis, keterbatasan relung dan kehilangan habitat, maka diusulkan untuk mengubah status perlindungannya dari Terancam Punah atau Endangered B2ab(iii) menjadi Rawan Punah atau Vulnerable B1ab(iii). Jenis ini diusulkan pula sebagai hewan indikator bagi perlindungan kawasan di Indonesia.

\section{INTRODUCTION}

Barbourula kalimantanensis Iskandar, 1978, is a frog with peculiar morphological adaptations (extreme flattening of the body, no lungs, and full webbing of the fingers) that lives in pristine, clear, fast, and coldrunning streams and is of great conservation interest because of severe recent habitat loss. It is the only member of the bombinatorid frog family in Indonesia and only found in Kalimantan, whereas the other members of the family, except Barbourula busuangensis Taylor \& Noble, 1924 (found in the Philippines), have a completely Palaearctic distribution (Iskandar 1978). Before the recent rediscovery, surveys of suitable habitat had not recovered any further populations, suggesting that this species has a very limited distribution and/or is very rare (IUCN 2006). Additionally, it may

Abbreviations: ANOVA, Analysis of Variance - AOO, Area of Occupancy; BBBR-NP - Bukit Baka-Bukit Raya - National Park; cyt b - cytochrome b; COI - cytochrome c oxidase subunit 1; DO - dissolved oxygen; EOO - Extent of Occurrence; ITB - Institut Teknologi Bandung; IUCN - International Union for the Conservation of Nature; NUS National University of Singapore; RMBR - Raffles Museum for Biodiversity Research; UNTAN - Universitas Tanjung Pura, Pontianak; VES - Visual Encounter Survey 
be facing extirpation or extinction as forest stream habitats upon which it is dependent are being heavily modified due to illegal gold mining and deforestation (IUCN 2006). Based on our previously limited data, the International Union for Conservation of Nature (IUCN) categorized B. kalimantanensis as Endangered, applying criteria B2ab(iii); i.e., extent of occurrence (EOO) of less than $5000 \mathrm{~km}^{2}$; all individuals in less than five locations and its forest habitat in Kalimantan is still in decline.

In order to conserve a species, accurate population, reproduction, ecology, and range information about the species are required to provide better assessment of conservation status and develop a feasible management plan. As information about B. kalimantanensis was previously incomplete, additional data were badly needed. Therefore, several expeditions were organized to confirm the species' geographic range in the wild (5-21 August 2007, 30 June-9 July 2008, 7-15 July 2009 and 25 March-14 April 2011). The expeditions studied the area around Bukit Baka Bukit Raya-National Park (BBBR-NP), around the border of West and Central Kalimantan Province $\left(00^{\circ} 35.228^{\prime}\right.$ $47.575^{\prime} \mathrm{S} \&$ \& $\left.112^{\circ} 14.195^{\prime}-19.241^{\prime} \mathrm{E}\right)$. We obtained nine specimens of $B$. kalimantanensis in 2007, two in 2008 and three others in 2009. Recently, a single specimen has been obtained on 10 April 2011, again from a production forest, northwest of the previously known distribution (Image 1). We discovered that this species is the first lungless frog (Bickford et al. 2008). This adaptation will have major consequences for the ecology and distribution of the species but we still know

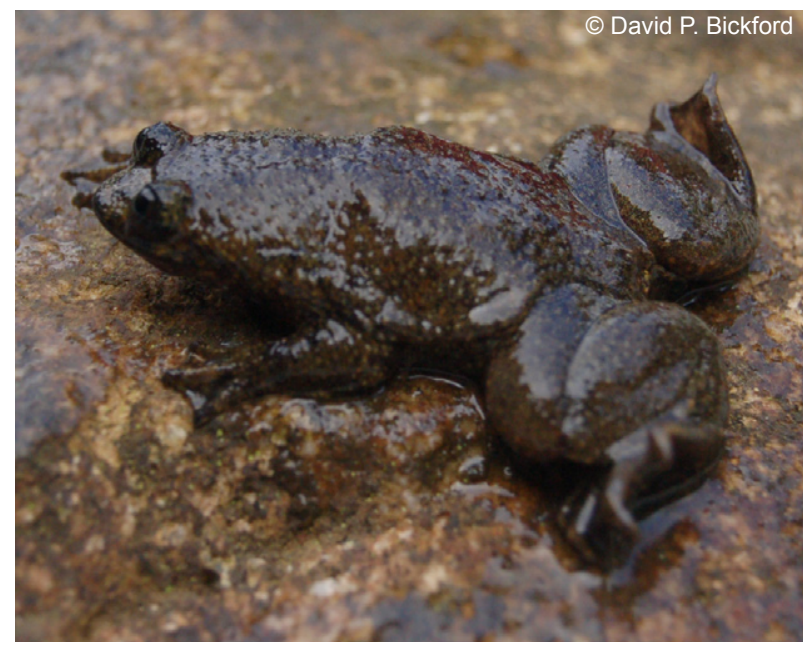

Image 1. Barbourula kalimantanensis very little about the species' ecology. In addition, we also obtained information about habitat and genetics. With this additional information, the extinction risks of this species can be better understood and mitigated. This paper summarizes this information and reviews the conservation status of $B$. kalimantanensis, making suggestions for a management strategy.

\section{METHODS}

\section{Field surveys}

We used VES, a method in which a team of five field personnel walked through the habitat of the frog (fast flowing streams $>4 \mathrm{~m}$ wide) from 1900 to midnight, to search for B. kalimantanensis (Heyer et al. 1994). We investigated eight streams at a lower elevation (200400 ) within the primary rain forest around BBBRNP (Fig. 1). Six streams (Seti, Bahae, Baras Bahae, Kelawai, Sahaur, and Sepilang of Katingan River, part of Mendawai River Basin) were in the Kalimantan Tengah Province, while the other two streams (Ela Hulu and Semunga, part of Melawi River Basin) were in the Kalimantan Barat Province. The streams' physico-chemical characteristics (DO, $\mathrm{pH}$, salinity, water temperature, and current speed) were assessed with a YSI 556 Multi-Probe system. The stream substrate was also sampled from three spots along each stream and sorted using a Tyler Standard Screen Scale. The substrate size compositions were then analyzed by cluster analysis and one way ANOVA.

\section{Genetic Analysis}

DNA Sequences: We used the DNeasy kit (QIAGEN), following the manufacturer's protocol, to isolate DNA from tissue samples for eight specimens of $B$. kalimantanesis. Two gene fragments were amplified, approximately $500 \mathrm{bp}$ of cyt b and $450 \mathrm{bp}$ of COI. We used the universal HCO2198 (5'- TAAACTTCAGGGTGACCAAAAAATCA -3') -LCO1490 primers (5'GGTCAACAAATCATAAAGATATTGG -3') to amplify COI (Folmer et al. 1994), and two alternative pairs of primers for cyt $b$ (because of primer binding problems for some individuals) (see Sheridan et al. 2010). We used the same PCR protocol as Folmer et al. (1994) and Sheridan et al. (2010) for the two COI and cyt b protocols, purified 


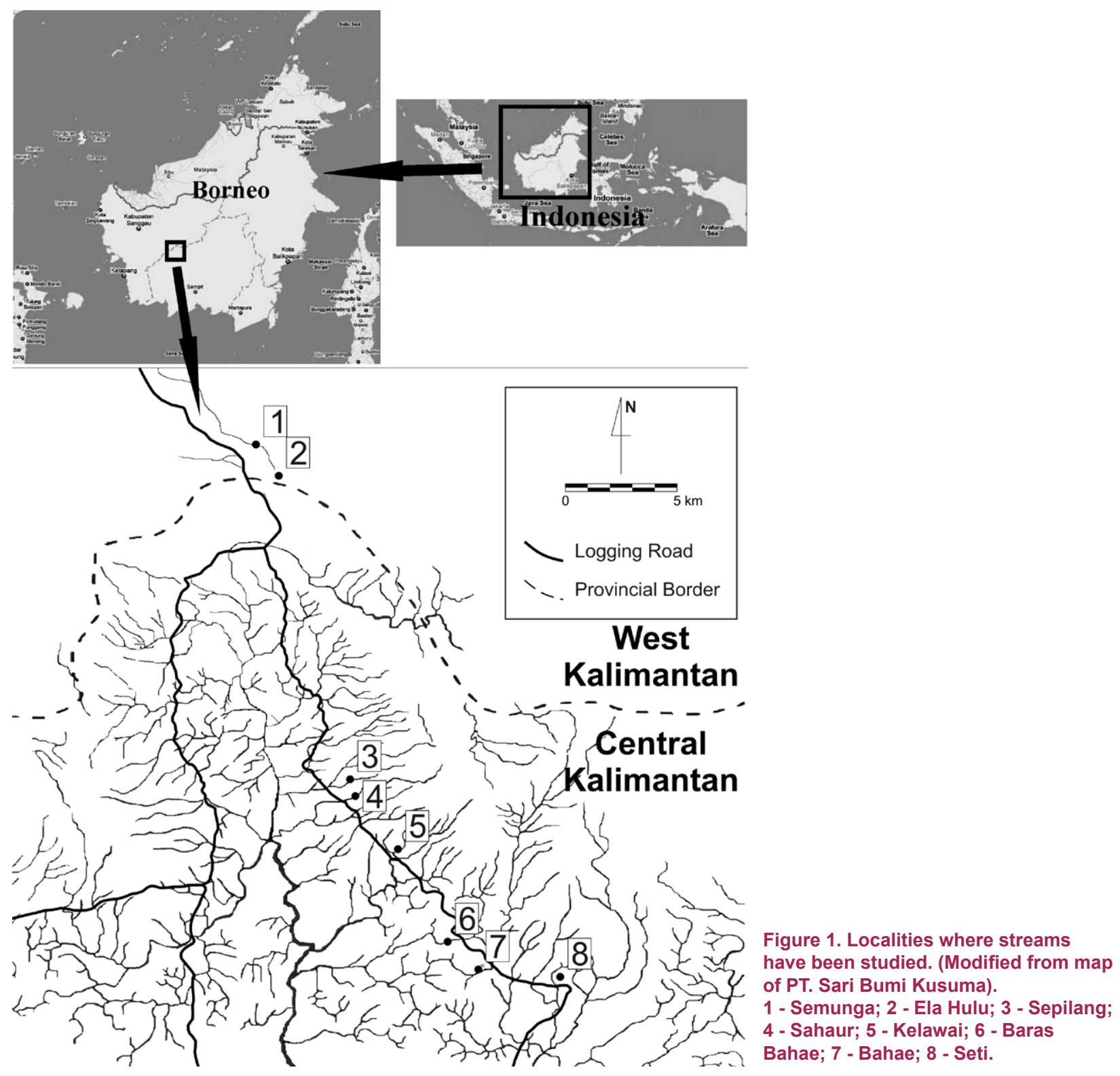

the PCR products with SureClean, cycle sequenced using BigDye Terminator v3.1, and cleaned again with Agencourt's CleanSEQ before being sequenced on an ABI 3130xl Genetic Analyzer. All sequences were aligned based on amino acid translations as described in Meier et al. (2006). In order to carry out a preliminary comparison of the intraspecific genetic variability of B. kalimantanesis with other archeobatrachian frogs, we used GenBank sequences for cyt b to quantify the intraspecific variability using uncorrected pairwise distances as determined in PAUP* (Swofford 2002). A similar comparison for COI was not carried out due to the lack of GenBank data for assessing the intraspecific variability across Archeobatrachia.

\section{RESULTS}

Rediscovery of the species with new additional specimens

We obtained nine specimens of $B$. kalimantanensis from two of eight streams sampled. One specimen was obtained from Ela Hulu stream in Melawi River Basin, West Kalimantan, and eight specimens from Bahae Stream; plus one, not collected specimen from Sahaur stream in Mendawai River Basin, Central Kalimantan in 2007 (Fig. 1). We also obtained two additional specimens from Bahae Stream in 2008 and three others in 2009 from the same site. From a recent independent survey, a single specimen has 


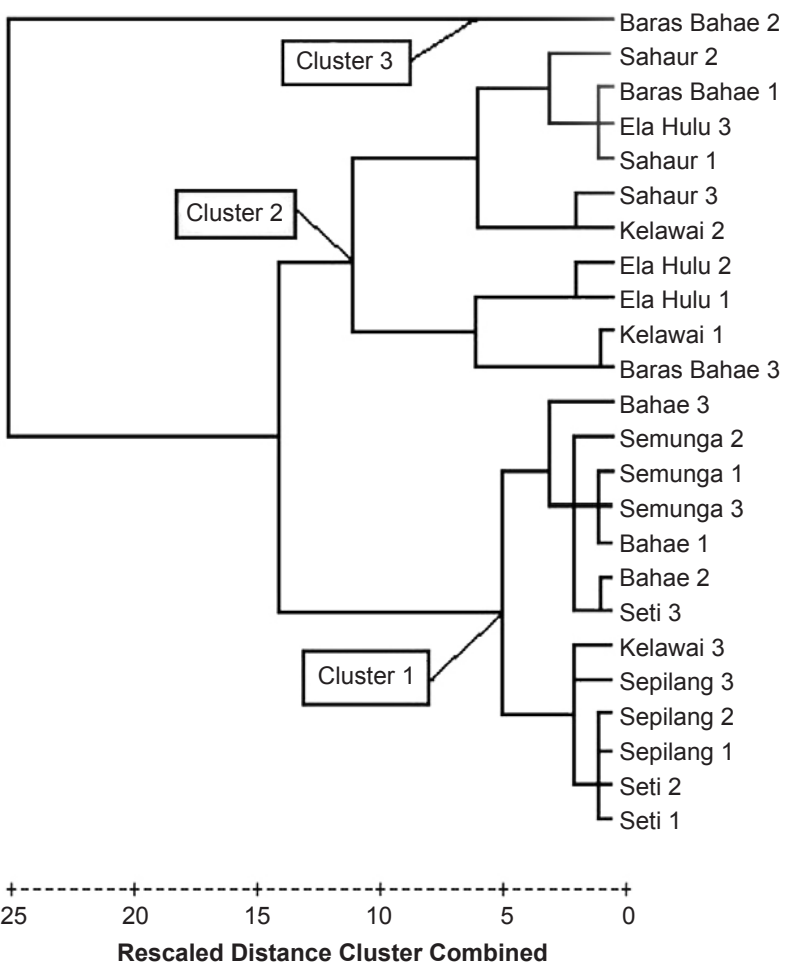

Figure 2. Result of cluster analysis based on the stream substrate.

been obtained from Melopang Stream $\left(00^{\circ} 35.228^{\prime} \mathrm{N}\right.$ \& $\left.112^{\circ} 14.195^{\prime} \mathrm{E}\right)$, Sokan River, another part of the Melawi Basin, West Kalimantan, bringing the total to 17 known specimens. Physico-chemical measurements of streams around BBBRNP where $B$. kalimantanensis were found revealed that the water is below $23^{\circ} \mathrm{C}$, usually $14-17^{\circ} \mathrm{C}$, with current speeds reaching $5 \mathrm{~m} / \mathrm{s}$. The DO averages $8.6 \mathrm{mg} / 1$ (100.5\%).

Results of cluster analysis of stream substrate showed that stream compositions varied between one another, however three clusters could be established (Fig. 2). Even though each cluster differed from the others significantly $(p<0.05)$, most clusters comprised of samples from different streams. Only one spot in the Baras Bahae Stream formed a separate cluster, caused by a large proportion of fine particles $(>40 \%$ are less than $0.25 \mathrm{~mm}$ ). Other streams, including Baras Bahae spot 1 and 3, are clustered together, either with Ela Hulu or with Bahae, indicating that they have a similar composition of substrate.

It is important to consider that the actual amount of suitable habitat within the range is small because it only consists of clear, fast, cold, and wide streams. The last discovery of the species from a small stream with
Genbank accession numbers:

\begin{tabular}{|l|c|l|}
\hline Mus No/ Voucher: & Acc COI: & Acc Cytb: \\
\hline ZRC/RMBR 934 & HM778123 & HM778130 \\
\hline ZRC/RMBR 939 & HM778124 & HM778131 \\
\hline ITB/RMBR 989 & - & HM778132 \\
\hline ITB/RMBR 1003 & HM778118 & HM778125 \\
\hline ITB/RMBR 1004 & HM778119 & HM778126 \\
\hline ZRC/RMBR 1005 & HM778120 & HM778127 \\
\hline ZRC/RMBR 1006 & HM778121 & HM778128 \\
\hline ITB/RMBR 1117* & HM778122 & HM778129 \\
\hline
\end{tabular}

Note: $\left(^{*}\right)$ Additional sequences for ITB/RMBR 1117: 12S-16S (mt): HM769263; CXCR4 (nuc): HM769266; NCX1 (nuc): HM769269; SLC8A3 (nuc): HM769272 (see Blackburn et al. 2010).

Table 1. Preliminary comparison of the intraspesific genetic variability of $B$. kalimantanensis with other archeobatrachian frogs

\begin{tabular}{|l|c|c|c|}
\hline Species & $\begin{array}{c}\text { No of } \\
\text { Sequences }\end{array}$ & $\begin{array}{c}\text { Median } \\
\text { Distance }\end{array}$ & Range \\
\hline Ascaphus truei & 31 & $2.06 \%$ & $0-9.7 \%$ \\
\hline Alytes obstetricans & 19 & $0.78 \%$ & $0-4.95 \%$ \\
\hline Discoglossus galganoi & 45 & $0.56 \%$ & $0-8.59 \%$ \\
\hline Discoglossus jeanneae & 49 & $0 \%$ & $0-0.85 \%$ \\
\hline Discoglossus pictus & 22 & $6.12 \%$ & $0-13.56 \%$ \\
\hline Barbourula kalimantanensis & 8 & $0.09 \%$ & $0-0.35 \%$ \\
\hline Bombina bombina & 113 & $0.37 \%$ & $0-6.43 \%$ \\
\hline Bombina variegata & 257 & $0.82 \%$ & $0-9.59 \%$ \\
\hline Bombina maxima & 9 & $0.90 \%$ & $0-6.02 \%$ \\
\hline
\end{tabular}

lots of cascades and slab rock bottom indicates that the species is potentially capable of staying in damp cool areas on land and might explore wider habitats other than streams, thus facilitating the ability to move from one to another place on land.

\section{Genetic Variations}

The eight cyt $b$ sequences belong to four haplotypes with one population being monomorphic (3 sequences) and sharing its haplotype with the second population (for GenBank accession numbers see supporting information). All haplotypes are very similar (uncorrected pairwise distances: 0.09-0.35\%; median distance: $0.09 \%$ ). Preliminary comparison of intraspecific genetic variability of Barbourula kalimantanesis with other archeobatrachian frogs using GenBank sequences for cyt $\mathrm{b}$ showed that the genetic variability of $B$. kalimantanesis is very low $(\mathrm{n}=8$; mean $0.09 \%$; range $0-0.35 \%)$ (Table 1 ). 


\section{DISCUSSION}

\section{The Occurrence of Barbourula kalimantanensis}

Barbourula kalimantanensis was previously recorded from only three localities, Pinoh (Iskandar 1978) and Kelawit River (Iskandar 1995) in the Melawi River Basin, West Kalimantan, and Tengkalap River (Santoso et al. 2006) in the Belantikan River Basin, Central Kalimantan. From expeditions to BBBR-NP and neighboring areas, nine additional specimens of B. kalimantanensis were obtained from three new localities, Ela Hulu and Melopang Stream, Sokan River, West Kalimantan; in the Melawi River Basin, West Kalimantan; Bahae Stream in the Mendawai River Basin, Central Kalimantan i.e., the species is now known from seven localities representing an EOO of more than $5,000 \mathrm{~km}^{2}$.

As the area around the type locality is now highly degraded due to illegal gold mining (IUCN 2006), much of the habitat is no longer suitable for B. kalimantanensis, and populations of this species in this area are assumed to be extirpated (Iskandar, unpub. data). As a result, two of the known sites are now lost, but we have at least three additional sites, which expand the EOO to above $5,000 \mathrm{~km}^{2}$. Stream connectivity suggests that the EOO of this species could be much larger than $5,000 \mathrm{~km}^{2}$. There are practically no geographic barriers between Ela Hulu and Bahae streams, though they are in different river basins on the same side of a small ridge. The area is relatively flat, and the headwaters adjacent to Ela Hulu (about $5 \mathrm{~km}$ away) are interconnected with Bahae, making the distance between them and the Melawi Basin drainage only about $8 \mathrm{~km}$ on the same gentle slope. The Melopang Stream, Melawi River Basin, extends far to the west and is very close to Pawan River Basin which flows to the west coast of West Kalimantan. It is only separated by about $5 \mathrm{~km}$ from the head water of Pawan River and can be located visually from the neighboring hilly area.

Compared to other archaeobatrachian frogs, the genetic variability of $B$. kalimantanesis is extremely low (Table 1). This probably indicates that the streams are historically well connected, with little isolation between populations of $B$. kalimantanensis in Melawi Basin and those in Mendawai Basin. As streams' connectivity occurs, not only between the head waters of Melawi and Mendawai Basin to the south, Melawi-
Pawan to the west, but also between head waters such as Mendawai-Seruyan, Mendawai-Sampit, Seruyan-Belantikan, Mendawai-Dayak Besar, and also perhaps Dayak Besar-Dayak Kecil. Judging from the topography most of the aforementioned streams have their headwaters on the same gentle slope of the Schwanner mountain range facing south. For that reason, the extent of occurrence of B. kalimantanensis could thus be much larger than previously thought. It might encompass all headwaters, from the foot of the Schwanner mountain range, through the Belantikan basin up to Dayak Kecil basin (Image 2). Although suitable habitat is undoubtedly patchy all along these rivers, EOO is still potentially much greater than had previously been revealed from the limited number of specimens prior to 2007 as shown in the present discoveries.

\section{Habitat Associations and Preference}

Barbourula kalimantanensis is a fully aquatic frog (Iskandar 1978) whose presence has always been associated with relatively shallow $(<1 \mathrm{~m})$, cold, fastflowing, clear, rocky streams in primary tropical rain forest (Iskandar 1978, 1995; Santoso et al. 2006). In fact, they seem to be inseparable, as $B$. kalimantanensis morphology shows extreme specialization for aquatic life in that specific habitat (Iskandar 1978; Bickford et al. 2008) which in turn reduces its ability to live elsewhere (Frazer 1973). As a lungless species, $B$. kalimantanensis needs higher levels of free oxygen that is only provided by shallow, clear, cold, fast flowing, and highly mixed streams. Physico-chemical measurements of streams clearly showed that the water is well aerated and oversaturated. In addition, none of the 14 specimens were caught among stones with dead leaves or other kinds of debris, probably avoiding water with less oxygen content caused by decomposing materials.

Bare rock and large stones are the major substrate of Barbourula kalimantanensis stream habitat and play an important role in the way this species lives. Large stones $(>30 \mathrm{~cm}$ in diameter) are used as cover; hiding under bigger rocks and/or camouflaging directly on the stream substrate. The streams' substrates also serve as home for benthic fauna which $B$. kalimantanensis preys upon. One individual of $B$. kalimantanensis (RMBR 1007, SVL 49mm) had the stomach filled with a large, barely digested aquatic dytiscid larva 


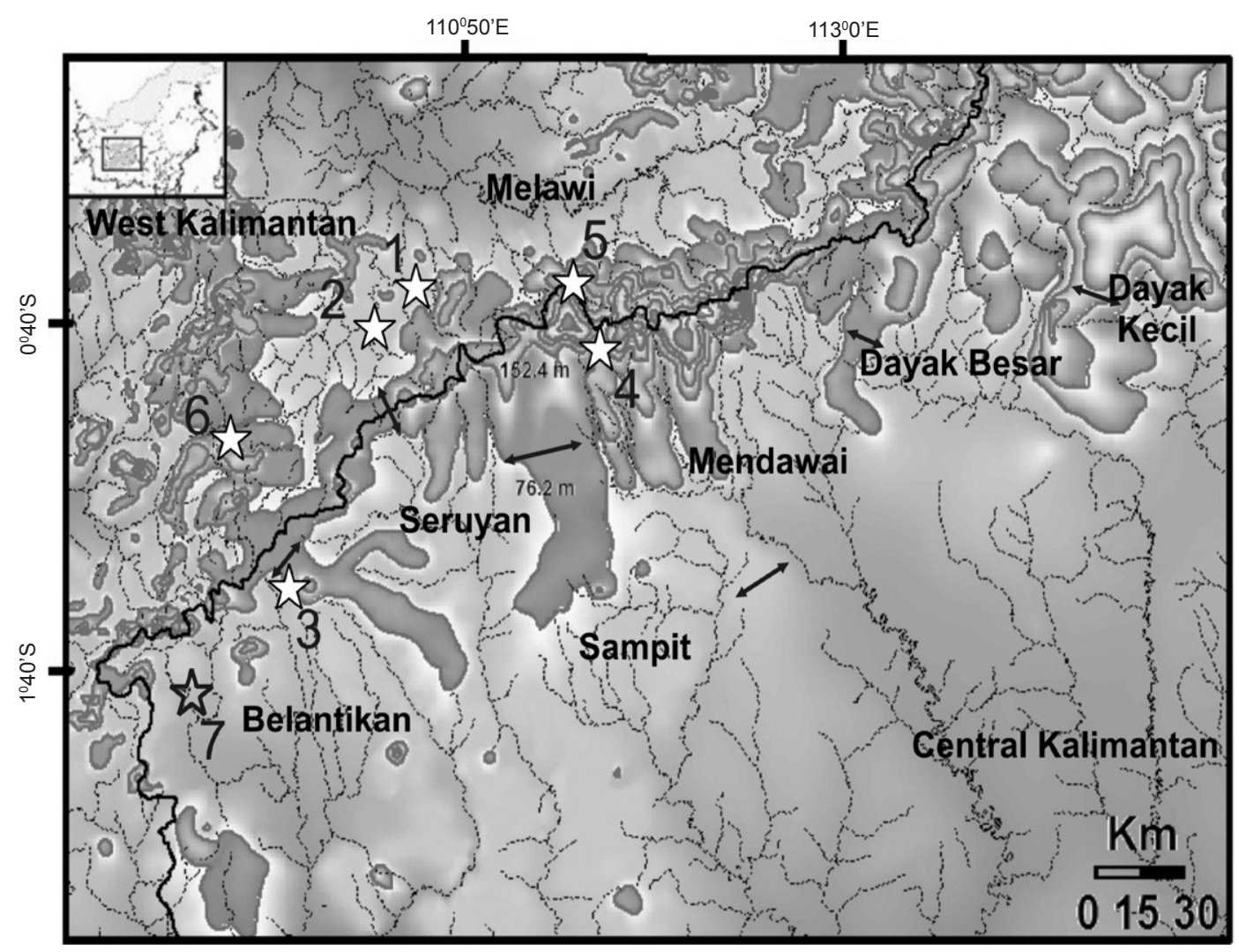

Image 2. Possible connections between river basins in West-Central Kalimantan, illustrated by the arrows. The nearby position between the head of streams in Melawi Basin-Mendawai Basin, Mendawai Basin-Seruyan Basin, MendawaiSampit, Seruyan Basin-Belantikan Basin, Mendawai-Dayak Besar, and then perhaps Dayak Besar-Dayak Kecil, implicated on the extension of $B$. kalimantanensis range much wider than was previously thought.

Legend: 1 - Nanga Pinoh, the type locality; 2 - Kelawit River; 3 - Tengkalap, Belantikan River; 4 - Bahae River, Mendawai Basin; 5 - Ela Hulu River; 6 - Melopang, Sokan River; 7 - Batang Kawa River, Lamandau District, East Kalimantan (potential site for Barbourula as reported by local people.

of 30x7 mm (LxW), with its abdomen crumpled and a single, undigested trichopteran larva. The recent captured specimen of $60 \mathrm{~mm}$ readily accepts small shrimp (Macrobrachium sp.) when kept in running water within a mesh cage. Considering its generally lethargic behavior, it is assumed that this species is a sit-and-wait predator of benthic fauna that pass by instead of actively looking for food.

From eight investigated streams, B. kalimantanensis were found only in Ela Hulu, Sahaur and Bahae streams. However, all streams were found to have similar substrate size and composition via cluster analysis of stream substrate samples. Other streams, except for Baras Bahae spot 2, were also clustered together, either with Ela Hulu or with Bahae, indicating that they shared the same composition of substrate, and could be the type of habitat suitable for B. kalimantanensis (Fig 2). The last discovery from a small, fast flowing stream with slate bedrock bottom and small cascades might indicate that the species can thrive on humid terrestrial habitat, analogous to many lungless salamanders of the North American forest (Welsh \& Droege 2001; Dillard et al. 2008).

\section{Threats}

For the time being, IUCN considers two major threat types for B. kalimantanensis, habitat loss and pollution mainly due to deforestation (logging) and gold mining. In logged areas, rocks in streams become coated with a thin layer of silt, and the food supply of benthic organisms is destroyed (Inger \& Stuebing 1995). Barbourula kalimantanensis, in addition to feeding on small shrimp species, is now known to feed on larva of Trichoptera and Dytiscidae, all are benthic organisms and the insect larvae are known to feed on algae (McDonald et al. 1990). Thus, the silting of streams caused by logging and illegal gold mining would affect the benthic populations of prey species 
negatively. In a logged area, water temperature is found to be warmer than in the non-logged area (Graynoth 1979; De Groot et al. 2007). The effect of temperature increase for $B$. kalimantanensis is clear. It causes oxygen concentrations to decrease as a consequence of lower solubility (Hill et al. 2008). This condition could seriously harm not only B. kalimantanensis, but other aquatic organisms as well. Similar to logged areas, gold mining activities also cause adverse habitat modifications for $B$. kalimantanensis. The headwaters of most streams in the region are intersected by logging roads and the future of these streams is in jeopardy. In addition to logging and heavy silting of roads, gold mining also contributes to the pollution of streams with highly toxic mercury.

Several other risk categories such as global warming, habitat specificity because of lunglessness, and very low genetic variability should be added to the list of extinction threats for this species. The influence of global warming upon B. kalimantanensis may not be recognized as yet, but it has been confirmed to affect amphibian populations and is the most likely candidate for causing extinction of Bufo periglenes (Stuart et al. 2004, 2008; Flannery 2005). Threat from Batrachochytrium dendrobatidis could be set aside as the area where $B$. kalimantanensis is known to occur is still remote from excessive human activities and not yet influenced by introduced plant and animal species. Lunglessness is a highly specialized adaptation for living in a specific habitat, effectively preventing the species from living elsewhere. As habitat degradation on Borneo is very extensive, lunglessness could become a major liability for this species. Any kind of change that alters water quality, especially oxygen content, would seriously affect this frog. The only recourse for survival is to retreat upstream. The very low genetic variability of this species also indicates the possibility of a recent bottleneck effect, though confirmation of such an event is still needed.

\section{A review to Barbourula kalimantanensis' IUCN conservation status}

Based on two specimens, IUCN (2006) categorized Barbourula kalimantanensis as Endangered B2ab(iii). This category was given in consideration of its area of occupancy (AOO), previously thought to be less than $500 \mathrm{~km}^{2}$, or an EOO of less than $5,000 \mathrm{~km}^{2}$. Now, as discussed above, we believe its present range area is more than $5,000 \mathrm{~km}^{2}$. As a consequence, its EOO in category $\mathrm{B}$ for Endangered species designation is no longer appropriate. Lunglessness has made $B$. kalimantanensis very susceptible to changes in water quality, especially oxygen content. Possible responses of $B$. kalimantanensis are to retreat upstream. As all specimens of $B$. kalimantanensis were discovered upstream near the stream headwaters and not lower down stream, Habitat degradation in those areas will be catastrophic. In the meantime, all of the interconnected streams and many of the headwaters shown in figure 1 are in the area of logging concession (Singleton et al. 2004). Within this area, the threat from logging is severe. Moreover, logged areas are prime targets for indigenous and newly arrived slash and burn agriculturists, further deteriorating water quality of the stream habitats. In addition, there is evidence that illegal mining is continuing up the watercourses around the area (Jarvie et al. 1998; present study). Based on this information, populations of B. kalimantanensis are exposed to tremendous threats of extirpation and extinction. Logging should be managed carefully, and if agriculture and gold mining continue, it will exacerbate extinction risks of all the known and presumed populations of $B$. kalimantanensis. Despite the threats from habitat degradation, and the low adaptability of $B$. kalimantanensis (lungless and low genetic variability), we recommend that this species be listed as a Vulnerable B1ab(iii), as more and more localities are discovered in the last decades and covering major watersheds in west and central Kalimantan. Some clean small streams with slab rock bottom, crevices and cascades are found to be the home of $B$. kalimantanensis as well.

\section{Conservation Efforts}

In Indonesia, no amphibian species is on the list of plants and animals protected by law (Dephut 2004). This condition is driven by lack of data supporting the importance of amphibian species as a component of ecosystems (Iskandar 2004), and by a lack of scientific monitoring efforts. Available data about $B$. kalimantanensis from this study might still be inadequate, but its unique adaptation and extreme specialization should be sufficient to garner attention from the Indonesian government. Besides, by following criteria of protected species from Indonesian Governmental Law no.7. 1999 (Noerdjito 
et al. 2005), B. kalimantanensis has already met at least two important criteria. The first criterion is living in a very specific and restricted habitat, and the second is low adaptability or ability to live elsewhere. Thus, we strongly suggest that the Indonesian government give more attention to this species, and put it on the list of protected species of Indonesia. In addition, protecting B. kalimantanensis means protecting the head waters and surrounding forest habitats, which for the time being, are subject to logging, fragmentation, other conversion threats (Singleton et al. 2004), and illegal gold mining activities (Lestariya 2005). Conserving B. kalimantanensis will thus also protect headwaters and affect forest quality.

At present, no additional specimens have been found inside Bukit Baka Bukit Raya National Park. However, as the rivers that feed into the Melawi and Katingan (Mendawai) rivers have some of their headwaters in the park, it is very likely that BBBRNP is the most likely place for a $B$. kalimantanensis sanctuary. The remoteness of the park and other known sites is one advantage, although it nevertheless faces many threats (Jarvie et al. 1998). Thus, the park, along with government and local people, should work together to maximize conservation of this species. Even though populations of $B$. kalimantanensis are exposed to tremendous threats of extirpation and extinction, there is still a good chance for this species to remain extant and sustain healthy populations in well-managed protected areas.

We propose that Barbourula kalimantanensis should become a flagship species for the park. Its endemicity, unique appearance, and lunglessness (as a special adaptation) will, without doubt, attract international attention and support. When public and scientific support has been generated, funding can be directed to maintain ecological processes and ecosystem integrity in streams and surrounding forest habitats, protecting not only this species, but also the remaining species in this area.

\section{Supporting Information:}

Material examined: MZB Amph. 2335 (holotype), adult male from Sungai Pinoh, south of Nanga Pinoh, by S. Wirjoatmodjo \& T. Roberts, July 1977. ZRC 1.32191 ex, adult female from Sungai Kelawai, $1 \mathrm{~km}$

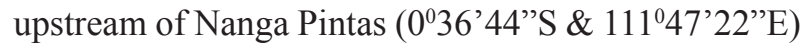
by M. Kottelat, 17.ix.1993; ITB coll (RMBR 989,
1003, 1004) 4 ex. (1 juv. female, 2 juv. males). ZRC coll. (RMBR 934, 939, 1005, 1006), 4 ex., (3 juv. females, 1 juv. male) from Bahae Stream, by D.T. Iskandar \& coll., 15-21.viii.2007. ITB coll. (RMBR 1007) 1 ex (juv. female). preserved in ethanol $70 \%$; ITB coll. RMBR 1117 from Ela Hulu Stream, D.T. Iskandar \& coll., 15-21.viii.2007; ITB coll. MK 721, 722 ( 1 adult male and 1 juv.) from Bahae Stream, by M. Kamsi. June 2008. ITB coll. (FN RMBR 2060-2062; 3 ex, juv.) from from Bahae Stream, by D.P. Bickford \& coll., July 2009. 10.iv.2011, AR 456 (1 ex.), from Melopang Stream, Sokan River, a part of the Melawi watershed, West Kalimantan, by A. Rachmansah.

\section{REFERENCES}

Bickford, D., D. Iskandar \& A. Barlian (2008). A lungless frog discovered on Borneo. Current Biology 8(9): 292-293.

Blackburn, D.C., D. Bickford, A. Diesmos, D.T. Iskandar \& R. Brown (2010). An ancient origin for the enigmatic Flat-Headed Frogs (Bombinatoridae: Barbourula) from the islands of Southeast Asia. PLoS ONE 5(8) e12090: 1-10.

De Groot, J.D., S.G. Hinch \& J.S. Richardson (2007). Effects of logging second-growth forests on headwater populations of coastal cutthroat trout: A 6-year, multistream, beforeand-after field experiment. Transactions of the American Fisheries Society 136: 211-226.

Dephut (Ministry of Foresty) (2004). Regulations and Laws Concerning Forest Protection and Conservation of Nature. Sekretariat Direktorat Jenderal Perlindungan Hutan dan Konservasi Alam, Jakarta. (in Indonesian), iii+617pp.

Dillard, L.O., K.R. Russell \& W.M. Ford (2008). Site-level habitat models for the endemic, threatened Cheat Mountain Salamander (Plethodon nettingi): the importance of geophysical and biotic attributes for predicting occurrence. Biodiversity \& Conservation 17: 1475-1492.

Flannery, T. (2005). The Weather Makers. The Text Publishing Company, Melbourne, 357pp.

Folmer, O., M. Black, W. Hoeh, R. Lutz \& R. Vrijenhoek (1994). DNA primers for amplification of mitochondrial cytochrome $c$ oxidase subunit I from diverse metazoan invertebrates. Molecular Marine Biology \& Biotechnology 3(5): 294-299.

Frazer, J.F.D. (1973). Amphibians. Wykeham Publications, London \& Winchester, xii+478pp.

Graynoth, E. (1979). Effects of logging on stream environments and faunas in Nelson. New Zealand. Journal of Marine \& Freshwater Research 13(1): 79-109.

Heyer, W.R., M.A Donnelly, R.W. McDiarmid, L.C. Hayek \& M.S. Foster (1994). Measuring and Monitoring Biological Diversity. Standard Methods for Amphibians. Smithsonian Institution Press, Washington and London, xix $+364 \mathrm{pp}$. 
Hill, R.W. G.A. Wyse \& M. Anderson (2008). Animal Physiology-2 $2^{\text {nd }}$ Edition. Sunderland, Sinauer Associates, USA, xxvi+770pp.

Inger, R.F. \& R.B. Stuebing (2005). A Field Guide to The Frogs of Borneo. Natural History Publication, Kota Kinabalu, vii+201pp.

Iskandar, D.T. (1978). A new species of Barbourula: first record of a discoglossid anuran in Borneo. Copeia 1978(4): 564-566.

Iskandar, D.T. (1995). Note on the second specimen of Barbourula kalimantanensis (Amphibia, Anura, Discoglossidae). Raffles Bulletin of Zoology 43: 309-311.

Iskandar, D.T. (2004). The Amphibians and Reptiles of Malinau Region, Bulungan Research Forest, East Kalimantan: Annotated Checklist with Notes on Ecological Preferences of the Species and Local Utilization. Center of International Forestry Research, Bogor, $\mathrm{v}+27 \mathrm{pp}$.

IUCN (International Union for Conservation of Nature), Conservation International, and Nature Serve (2006). Global Amphibian Assessment. Available from http://www.globalamphibians.org (Accessed October 2007).

Jarvie, J.K., Ermayanti, U. Mahyar, A. Church \& Ismail (1998). The habitats and flora of Bukit Baka-Bukit Raya National Park. Tropical Biodiversity 5(1): 11-56.

Lestariya, A.W. (2005). Management of Melawi watersheds. Jurnal llmiah Geomatika 11(2): 1-13 (in Indonesian).

McDonald, B., W. Borden \& J. Lathrop (1990). Citizen stream Monitoring: A Manual for Illinois. Illinois Department of Energy and Natural Resources, ILENR/ RE-WR-90/18, Illinois, 96pp.

Meier, R., S. Kwong, G. Vaidya \& P.K.L. Ng (2006). DNA Barcoding and taxonomy in Diptera: a tale of high intraspecific variability and low identification success. Systematic Biology 55: 715-728.

Noerdjito, M., I. Maryanto, S.N. Prijono, E.B. Waluyo, R. Ubaidillah, Mumpuni, A.H. Tjakrawidjaja, R.M. Marwoto, W.A. Noerdjito \& H. Wiriadinata (2005). Criterion of Biodiversity that Need to be Protected by and for Indonesian Community (Kriteria jenis hayati yang harus dilindungi oleh dan untuk masyarakat Indonesia). LIPI, Bogor, (in Indonesian), xiii+97pp.

Santoso, E., S. Shonleben, I. Sapari \& L.A. Sadikin (2006). Barbourula kalimantanensis Iskandar, 1978 - a new record for Central Kalimantan, Indonesian Borneo (Amphibia: Anura: Discoglossidae). Herpetological Bulletin 98: 6-8.

Sheridan. A., D.P. Bickford \& K.F.-Y. Su (2010). An examination of call and genetic variation in three wide-ranging Southeast Asian anuran species. Raffles Bulletin of Zoology 58: 369-379.

Singleton, I., S. Wich, S. Husson, S. Stephens, S.U. Atmoko, M. Leighton, N. Rosen, K. Traylor-Holzer, R. Lacy \& O. Byers (eds.) (2004). Orangutan population and habitat viability assessment: Final Report. IUCN/SSC Conservation Breeding Specialist Group, Apple Valley, MN, 88pp.

Stuart, S.N., J.S. Chanson, N.A. Cox \& B.E. Young (2004). Status and trends of amphibian declines and extinctions worldwide. Science 306: 1783-1786.

Stuart, S.N., M. Hoffmann, J.S. Chanson, N.A. Cox, R.J. Berridge, P. Ramani \& B.E. Young (eds.) (2008). Threatened Amphibians of the World. Lynx Edicions, Barcelona, Spain; IUCN, Gland, Switzerland; and Conservation International, Arlington, Virginia, USA, $\mathrm{xV}+758 \mathrm{pp}$.

Swofford, D. L. (2002). PAUP*. Phylogenetic Analysis Using Parsimony (*and other Methods). Version 4. Sinauer Associates, Sunderland, Massachusetts, 142pp.

Taylor, E.H \& G.K. Noble (1924). A new genus of discoglossid frogs from the Philippine Islands. American Museum Novitates 121: 1-4.

Welsh, H.H.Jr. \& S. Droege (2001). A case for using plethodontid salamanders for monitoring biodiversity and ecosystem integrity of North American forests. Conservation Biology 15: 558-569.
Authors Details: BIOFAGRI A. RACHMAYUNINGTYAS and UMILAELA ARIFIN are both graduate students in Biology. Both are working on the taxonomy, ecology and conservation. DAVID P. BICKFORD is an Assistant Professor at National University of Singapore. His research is focused on reptiles and amphibians, their ecology and evolution, understanding adaptive radiations, and biogeography. MISTAR KAMSI is a freelance researcher in biology and conservation. $\mathrm{He}$ is mainly interested in amphibians and reptiles biology. Rudolf MeIER, Associate Professor at National University of Singapore and his assistant SUJATHA N. KUTTY focused on molecular genetics, phylogenetic relationships, mainly on insects. ANGGA RACHMANSAH is a graduate student in biology and engaged as a part timer surveyor at Fauna \& Flora InternationalIndonesia program, working on the ecology and conservation of amphibians and reptiles. DJoko T. ISKANDAR is the team leader and working as full Professor in Ecology and Biosystematics at School of Life Sciences and Technology, Institut Teknologi Bandung, working extensively on the herpetofauna of Southeast Asia and AustraloPapua.

Author Contributions: BAR and UA are responsible for data gathering in the field, data analysis, preparing figures and writing. DPB is involved in the first expedition and also responsible for the third expedition, arrange for funding, analysis, photographing and writing. $\mathrm{He}$ is mainly responsible in the paper writing, restructuring and very active in discussion about the content of this work. MK is responsible for the second expedition, mainly involved in finding specimens during the first and second expeditions, photographing and writing. RM and SNK are responsible in the genetic analysis and writing. AR is responsible in acquiring more data on Barbourula kalimantanensis since the first expedition up to present. DTI is the leader for the first expedition, arrange for logistics, permits and writing and preparing figures.a

Acknowledgments: Fieldwork for this research was funded by the National University of Singapore under DPB's startup R-154-000-383133 and the cryptic species project R-154-000270-112 and Mohammed bin Zayed species conservation fund. We acknowledge the help of Drs. E. Effendy (former) and Widada, Heads of the Bukit Baka-Bukit Raya National Park who accorded us to work and collect samples. We also appreciate Mr. D. Liswanto (Titian Foundation, FFI), who coordinates logistics for the field trips in 2008 and 2011. Our sincere thanks are addressed to S. Howards and Dr. H.H. Tan from National University of Singapore, and the other students and colleagues, $\mathrm{K}$. Indraswari, G. Ramadhan, L.R. Aditya, N. Firdaus, (ITB) and H.N. Tokan, Mediyansyah, H. Hasymi, D. Aryadi, D. Aryadi, B. Susilo (UNTAN), who helped us in the field. 